\title{
INTEGRATION OF OIL MARKETS IN INDIA
}

\section{A. ARUNA KUMARI ${ }^{1}$, D. V. SUBBARAO ${ }^{2}$ \& K. SUSEELA ${ }^{3}$}

${ }^{I}$ Teaching Associate, Department of Agricultural Economics, Agril College, Bapatla, Andhra Pradesh, India

${ }^{2}$ NABARD Chair Professor, Acharya N G Ranga Agricultural University, Guntur, Andhra Pradesh, India

${ }^{3}$ Assistant Professor, Department of Agricultural Economics, Agril College, Bapatla, Andhra Pradesh, India

\begin{abstract}
The present study was undertaken to assess the market integration of oils in India. Secondary data on monthly wholesale prices were collected for the period of 24 years, i.e., from 1980-81 to 2003-04. The data were collected from Agricultural prices in India. Price series correlation and Augmented Dicky Fuller (ADF) test were used as analytical tools. The results revealed that the selected oil markets for groundnut, rapeseed and mustard, castor and sesame were well integrated at the same order and there is existence of integration of prices between the above oil markets in India. These results have important policy implications in a situation when oil markets are spatially integrated and the government was thiningk of reducing or even withdrawing its efforts to influence the price in the market.

KEYWORDS: Market Integration, Oils, Price Series Correlation, Co integration, ADF Test \& India
\end{abstract}

Received: May 15, 2017; Accepted: Jun 02, 2017; Published: Jun 28, 2017; Paper Id.: IJASRAUG20177

\section{INTRODUCTION}

Although India ranks fourth among the largest producers of oilseeds in the world such as USA, China and Brazil, its productivity is quite low. The low and fluctuating yields are primarily due to a large part of the cultivation being on marginal lands lacking irrigation and with low levels of input usage. Three oilseeds: groundnut, soybean and rapeseed/mustard, together account for over 80 per cent of aggregate cultivated oilseeds output. The edible oils/ oilseeds sector currently faces several challenges. Oilseed cultivation is becoming increasingly unattractive due to low and unstable yields. The marketing system for oilseeds and edible oils has been characterized by government intervention with varying nature and degree of controls and regulations since 1970. A large spread at each level is considered to be a manifestation of market imperfections and poor competitiveness of the oilseed sector. As a result, while growers are deprived of fair returns for their produce, and they face uncertainty in their incomes and production disincentives, the consumers may find it difficult to access the goods at the right time and at reasonable prices (Chand, 2007). In a perfectly competitive market, commodity prices should move in unison in response to the forces of demand and supply. The accuracy and speed at which price change in one market (commodity) gets transmitted to other markets (close substitutes) is taken as an indicator of integration (interdependence) among the markets (commodity groups). The extent of integration gives signals for efficient resource allocation, which is considered essential for ensuring greater market efficiency, price stability and food security. Test of integration also plays a key role in determining the geographical level at which agricultural price policy should be targeted, at least in the short-run to ensure regular availability of food and price stability (Jha et al., 2005; Acharya, 2001). Markets that are not integrated may convey inaccurate price information that might distort marketing decisions and contribute to inefficient producing movements. Hence a study has been undertaken to analyze the integration of oil markets in India. 


\section{METHODOLOGY}

Integration among the selected oil markets over a period of time i.e., 1980-81 to 2003-04 was examined by employing co integration model. Market integration is defined as a situation in which arbitrage causes prices to move together in different markets. Thus, more specifically, two markets may said to be spatially integrated whenever trade takes place between them, if the price differential for homogenous commodity equals the transfer costs involved in moving that commodity. However, imperfections in the market, particularly those arising from activities of traders are generally taken as important causes of the existence of differential price movements in different markets. Spatial price relationships have been widely used to indicate overall market performance. The usual definition in the literature is that integrated markets are those where prices are determined interdependently. This has generally been assumed to mean that the price changes in one market will be fully transmitted to other markets. Markets that are not integrated may convey inaccurate price information that might distort marketing decisions and contribute to inefficient producing movements. So, it is necessary to compare market prices of oils. For the present study different oil markets, groundnut oil, rapeseed and mustard oil, castor oil and sesame oil were selected. For groundnut oil six markets were selected, namely Hyderabad, Rajkot, Bangalore, Mumbai, Calcutta and Delhi. For rapeseed and mustard oil also six markets were selected, namely Patna, Moga, Rothak, Hapur, Calcutta and Laha. For castor oil, six markets were selected, namely Hyderabad, Bangalore, Mumbai, Chennai, Kanpur and Calcutta. For sesame oil, four markets were selected, namely Hyderabad, Mumbai, Chennai and Varanasi. A bivariate price correlation as well as methodology developed by Engle and Granger (1987) have been used to assess whether oil markets are integrated or not.

\section{Price Series Correlation}

Price in one market does vary with the actions of buyers and sellers of other markets. The degree to which price information in one market is related to the process of the price information in other markets can be shown through zeroorder correlation matrix of prices in these markets. The approach presumes that with the random price behavior expected of a non-integrated market, the bi variant correlation coefficient of price movements will tend to be zero. Conversely, in a perfectly integrated market, correlation coefficient of price movements is expected to be unity. The simple correlation coefficient for the prices in each pair of selected markets can be estimated by the following formula:

$$
\begin{aligned}
& \mathrm{r}=\frac{\sum\left(p_{1} i-p_{1}\right)\left(p_{2} i-p_{2}\right)}{\sqrt{\sum\left(p_{1} t-p_{1}\right)\left(p_{2} t-p_{2}\right)}} \\
& \text { Where, } \\
& \mathrm{r}=\text { Simple correlation coefficient } \\
& \mathrm{P}_{1}{ }^{\mathrm{i}}=\text { Price of the commodity in the first market at } \mathrm{i}^{\text {th }} \text { point of time } \\
& \mathrm{P}_{2}{ }^{\mathrm{i}}=\text { Price of the commodity in the second market at } \mathrm{i}^{\text {th }} \text { point of time } \\
& \overline{\mathrm{P}}_{1}=\text { Mean of prices in the first market } \\
& \overline{\mathrm{P}}_{2}=\text { Mean of prices in the second market }
\end{aligned}
$$

The estimates of correlation coefficients were tested for their significance against zero by using " $\mathrm{t}$ " test and against one by Fisher's " $Z$ ” transformation and standard normal distribution test. 


\section{Unit Root and Cointegration Test}

To examine the price relation between two markets, the following regression model was used.

$P_{i t}=a_{0}+a_{1} P_{j t}+E_{t}---$

Where $\mathrm{P}_{\mathrm{i}}$ and $\mathrm{P}_{\mathrm{j}}$ are price series of a specific commodity in two markets $\mathrm{i}$ and $\mathrm{j}$ and $\mathrm{E}$ is the residual term assumed to be distributed identically and independently. Parameter $\mathrm{a}_{0}$ represents domestic transportation costs, processing costs and sales tax, etc. The test of market integration is straight forward if $P_{i}$ and $P_{j}$ are stationary variables. Often; however, economic variables are non-stationary in which case the conventional tests are based towards rejecting the null hypothesis. Thus, before proceeding with further analysis, the stationary of the variables needs to be checked (Granger and Newbold, 1977)

Stationary series is defined as one whose parameters that describe the series (namely the mean, variance and auto correlation) are independent of time, or rather exhibit constant mean and variance and have an auto correlation that are invariant through time. Thus a series is said to be stationary if its mean and variance are constant over time and the value of the covariance between two time periods depends only on the distance or lag between the two time periods and not on the actual time at which the covariance is computed. Once the non-stationary of the variables is determined, the next step is to test for the presence of co integrating (long-run equilibrium) relationships between the variables.

To test the univariate price series for stationary, the Augmented Dickey-Fuller (ADF) test has been applied, which tests the null hypothesis of non-stationary against an alternative of stationary.

The standard equation of the ADF test is:

$\Delta \mathrm{P}_{\mathrm{t}}=\mathrm{q}+(\mathrm{a}-1) \mathrm{P}_{\mathrm{t}}-1+\sum_{\mathrm{i}=1} \mathrm{Ci} \Delta_{\mathrm{pt-I}}+\mathrm{u}_{\mathrm{t}}---(2)$

The test statistic is simply the " $\mathrm{t}$ " statistic, however, under the null hypothesis, it is not distributed as student "t", but the ratio can be compared with critical values tabulated in Fuller (1976). In estimating equation (2), the $H_{0}$ is: $P_{t}$ is $1(1)$ which is rejected (in favor of 1(0), if a-1 is found to be negative and statistically significant.

The definition of co integration used here is that of Engle and Granger (1987). Before proceeding to test for market integration using the Co integration, analysis, the nature of the integration of the variables needs to be determined. The test involved regressing the first difference of the residual series of residual lagged level and lagged dependent variables is as follows:

$$
\Delta \mathrm{E}_{\mathrm{t}}=\mathrm{Y}_{1}+\mathrm{E}_{\mathrm{t}-1}+\sum_{k=1}^{N} O_{\mathrm{k}} \mathrm{E}_{\mathrm{t}-\mathrm{k}}+\mathrm{V}_{\mathrm{t}}
$$

Again the test statistic is the "t" statistic of $\mathrm{Y}_{1}$. The critical values are tabulated in Davidson-Mackinnon (1993, Table 20.2, p722) if the estimated " $\mathrm{t}$ " value for any of the price series market pair exceeds the critical values it indicates that the price series are co integrated.

\section{RESULTS AND DISCUSSIONS}

\section{Price Series Correlation}

Groundnut Oil: When calculated using the nominal price series for groundnut oil in six selected markets in India, the bivariate correlation coefficients ranged between 0.87 and 0.95 (Table1). The highest "r" value was observed for the market pair containing Hyderabad and Calcutta and the lowest was observed for the market pair Rajkot and Delhi. The 
results indicated that all the price series are efficiently correlated among the selected markets in India.

Table 1: Estimates of Correlation Coefficients for Monthly Wholesale Prices of Groundnut Oil between Pairs of Selected Markets in India (1980-81 through 2003-04)

\begin{tabular}{|l|c|c|c|c|c|c|}
\hline \multicolumn{1}{|c|}{ Markets } & Hyderabad & Rajkot & Bangalore & Mumbai & Calcutta & Delhi \\
\hline Hyderabad & 1.0000 & 0.9445 & 0.9182 & 0.9310 & 0.9501 & 0.9035 \\
\hline Rajkot & & 1.0000 & 0.9159 & 0.9142 & 0.9134 & 0.8748 \\
\hline Bangalore & & & 1.0000 & 0.9464 & 0.9134 & 0.8933 \\
\hline Mumbai & & & & 1.0000 & 0.9346 & 0.9054 \\
\hline Calcutta & & & & & 1.0000 & 0.9120 \\
\hline Delhi & & & & & & 1.0000 \\
\hline
\end{tabular}

Rapeseed and Mustard Oil: The results showed the bi variant correlation coefficients ranged between 0.75 and 0.99 (Table 2). The highest "r" value was observed for the market pair containing Kanpur and Calcutta and the lowest for the market pair containing Haryana and Delhi. The results indicated that all the price series were efficiently correlated among selected markets in India.

Table 2: Estimates of Correlation Coefficients for Monthly Wholesale Prices of Rapeseed and Mustard Oil between Pairs of Selected Markets in India (1980-81 through 2003-04)

\begin{tabular}{|l|c|c|c|c|c|c|}
\hline Markets & Patna & Moga & Haryana & Kanpur & Calcutta & Delhi \\
\hline Patna & 1.0000 & 0.8946 & 0.8721 & 0.9559 & 0.9648 & 0.8686 \\
\hline Moga & & 1.0000 & 0.9056 & 0.9254 & 0.9249 & 0.8047 \\
\hline Haryana & & & 1.0000 & 0.8871 & 0.8909 & 0.7548 \\
\hline Kanpur & & & & 1.0000 & 0.9878 & 0.8789 \\
\hline Calcutta & & & & & 1.0000 & 0.8782 \\
\hline Delhi & & & & & & 1.0000 \\
\hline
\end{tabular}

Castor Oil: The results showed the bi variant correlation coefficients ranged between 0.58 and 0.99 (Table 3). The highest " $r$ " value was observed for the market pair containing Madras and Kanpur and the lowest for the market pair containing Bangalore and Calcutta. The results indicated that all the price series were efficiently correlated among selected markets in India.

Table 3: Estimates of Correlation Coefficients for Monthly Wholesale Prices of Castor Oil between Pairs of Selected Markets in India (1980-81 through 2003-04)

\begin{tabular}{|l|c|c|c|c|c|c|}
\hline \multicolumn{1}{|c|}{ Markets } & Hyderabad & Bangalore & Mumbai & Madras & Kanpur & Calcutta \\
\hline Hyderabad & 1.0000 & 0.8171 & 0.9303 & 0.9577 & 0.9510 & 0.9114 \\
\hline Bangalore & & 1.0000 & 0.8444 & 0.9116 & 0.9102 & 0.5828 \\
\hline Mumbai & & & 1.0000 & 0.9253 & 0.9231 & 0.8408 \\
\hline Madras & & & & 1.0000 & 0.9879 & 0.8184 \\
\hline Kanpur & & & & & 1.0000 & 0.8195 \\
\hline Calcutta & & & & & & 1.0000 \\
\hline
\end{tabular}

Sesame Oil: The results showed the bi variant correlation coefficients ranged between 0.70 and 0.96 (Table 4). The highest " $r$ " value was observed for the market pair containing Hyderabad and Chennai and the lowest for the market pair containing Mumbai and Varanasi. The results indicated that all the price series were efficiently correlated among selected markets in India. 
Table 4: Estimates of Correlation Coefficients for Monthly Wholesale Prices of Sesame Oil between Pairs of Selected Markets in India (1980-81 through 2003-04)

\begin{tabular}{|l|c|c|c|c|}
\hline \multicolumn{1}{|c|}{ Markets } & Hyderabad & Mumbai & Chennai & Varanasi \\
\hline Hyderabad & 1.0000 & 0.8718 & 0.9642 & 0.7368 \\
\hline Mumbai & & 1.0000 & 0.8690 & 0.7013 \\
\hline Chennai & & & 1.0000 & 0.7140 \\
\hline Varanasi & & & & 1.0000 \\
\hline
\end{tabular}

\section{Augmented Dickey Fuller (ADF) Test}

Groundnut Oil: The results of the ADF test were presented in Table 5. The results would show that to the original level, the "t" calculated values were $-1.06,-1.19,-1.52,-1.03,-0.25$ and -0.92 in Hyderabad, Bangalore, Mumbai, Calcutta and Delhi markets respectively. All these values were less tan asymptotic critical value -2.57 under constant and no trend, but at the first difference (n-1 level), these "t" calculated values were $-4.54,-7.00,-4.54,-4.49,-4.76$ and -4.47 respectively for the same markets, which was greater than the critical value. It indicated that all the price series were stationary and had the same order of integration denoted by 1 (1). The results also showed that all the price series were having the same order of integration, and hence there was no need to go for further tests. If any series is having the same order of integration it may constitute a potential co integration relationship (Gujarati, 1996). Hence there was the existence of integration of prices between the selected groundnut oil markets in India.

Rapeseed and Mustard Oil: The results of the ADF test were presented in Table 6. The results showed that to the original level, the "t" calculated values were $-0.81,-2.23,-1.40,-0.95,-0.72$ and -1.21 in Patna, Moga, Haryana, Kanpur, Calcutta and Delhi markets respectively. All these values were less tan asymptotic critical value -2.57 under constant and no trend, but at the first difference (n-1 level), these "t" calculated values were $-5.57,-5.74,-5.29,-4.47,-4.73$ and -5.67 respectively for the same markets, which was greater than the critical value. It indicated that all the price series were stationary and had the same order of integration denoted by 1(1). So there was the existence of integration of prices between the selected Rapeseed and Mustard oil markets in India.

Castor Oil: The results of the ADF test were presented in Table 7. The results showed that to the original level, the " $\mathrm{t}$ " calculated values were $-1.39,-0.31,-1.20,-0.30,-0.58$ and -1.16 in Hyderabad, Bangalore, Mumbai, Chennai, Kanpur and Calcutta markets respectively. All these values were less tan asymptotic critical value -2.57 under constant and no trend, but at the first difference ( $\mathrm{n}-1$ level), these " $\mathrm{t}$ " calculated values were $-4.41,-5.01,-4.41,-4.47,-3.78$ and -4.29 respectively for the same markets, which was greater than the critical value. It indicated that all the price series were stationary and had the same order of integration denoted by 1(1). So there was the existence of integration of prices between the selected castor oil markets in India.

Sesame Oil: The results of the ADF test were presented in Table 8. The results showed that to the original level, the " $\mathrm{t}$ " calculated values were $-0.65,-0.44,-0.87$ and -1.74 in Hyderabad, Mumbai, Chennai and Varanasi markets respectively. All these values were less tan asymptotic critical value -2.57 under constant and no trend, but at the first difference ( $n-1$ level), these " $t$ " calculated values were $-4.03,-4.09,-3.75$ and -6.13 respectively for the same markets, which was greater than the critical value. It indicated that all the price series were stationary and had the same order of integration denoted by 1 (1). So there was the existence of integration of prices between the selected sesame oil markets in India.

To sum up, under price series correlation, all the selected oil markets, namely groundnut oil, rapeseed and mustard 
oil, castor oil and sesame oil in India were well integrated with a high degree of pricing efficiency. The values of correlation coefficients in most cases ranged between 0.8 and 0.9. Under Augmented Dicky Fuller (ADF) test also, the above oil markets in India were well integrated which indicated that all the price series were stationary with the same order of integration denoted by 1 (1).

Table 5: Unit Root Tests for Groundnut Oil Price Series in Selected Groundnut Oil Markets in India-Original First and Second Level (1980-81 through 2003-04)

\begin{tabular}{|c|c|c|c|c|c|c|c|}
\hline \multicolumn{8}{|c|}{ a) Original Level } \\
\hline \multirow[b]{2}{*}{ Variable } & \multirow[b]{2}{*}{ Lags } & \multicolumn{2}{|c|}{ Constant, No Trend } & \multicolumn{3}{|c|}{ Constant, Trend } & \multirow[t]{2}{*}{ Inference } \\
\hline & & $\mathbf{A}(\mathbf{1})=\mathbf{0}$ & $\begin{array}{c}\mathbf{A}(\mathbf{0})= \\
\mathbf{A}(\mathbf{1})=0\end{array}$ & $\mathbf{A}(\mathbf{1})=\mathbf{0}$ & $\begin{array}{c}\mathbf{A}(\mathbf{0})= \\
\mathbf{A}(\mathbf{1})= \\
\mathbf{A}(2)=\mathbf{0}\end{array}$ & $\begin{array}{c}\mathbf{A}(1)= \\
\mathbf{A}(2)=0\end{array}$ & \\
\hline $\begin{array}{l}\text { Critical value } \\
\text { (10 per cent) }\end{array}$ & & -2.57 & 3.78 & -3.13 & 4.03 & 5.34 & \\
\hline Hyderabad & 5 & -1.06 & 1.51 & -3.89 & 5.72 & 7.59 & Accept $\mathrm{H}_{0}$ \\
\hline Rajkot & 8 & -1.19 & 1.75 & -3.59 & 5.03 & 6.46 & Accept $\mathrm{H}_{0}$ \\
\hline Bangalore & 10 & -1.52 & 2.17 & -1.98 & 2.23 & 2.33 & Accept $\mathrm{H}_{0}$ \\
\hline Mumbai & 11 & -1.03 & 1.93 & -3.54 & 5.16 & 6.27 & Accept $\mathrm{H}_{0}$ \\
\hline Calcutta & 15 & -0.25 & 2.07 & -3.28 & 5.08 & 5.50 & Accept $\mathrm{H}_{0}$ \\
\hline Delhi & 4 & -0.92 & 1.70 & -3.50 & 4.97 & 6.13 & Accept $\mathrm{H}_{0}$ \\
\hline \multicolumn{8}{|c|}{ b) First Difference Level } \\
\hline \multirow[t]{2}{*}{ Variable } & Lags & \multicolumn{2}{|c|}{ Constant, No Trend } & \multicolumn{3}{|c|}{ Constant, Trend } & Inference \\
\hline & & $\mathbf{A}(\mathbf{1})=\mathbf{0}$ & $\begin{array}{c}\mathbf{A}(\mathbf{0})= \\
\mathbf{A}(\mathbf{1})=\mathbf{0}\end{array}$ & $\mathbf{A}(\mathbf{1})=\mathbf{0}$ & $\begin{array}{c}\mathbf{A}(0)= \\
\mathbf{A}(\mathbf{1})= \\
\mathbf{A}(2)=0\end{array}$ & $\begin{array}{c}\mathbf{A}(1)= \\
\mathbf{A}(2)=0\end{array}$ & \\
\hline $\begin{array}{l}\text { Critical value } \\
\text { (10 per cent) }\end{array}$ & & -2.57 & 3.78 & -3.13 & 4.03 & 5.34 & \\
\hline Hyderabad & 12 & -4.54 & 10.32 & -4.54 & 6.90 & 10.33 & Reject $\mathrm{H}_{0}$ \\
\hline Rajkot & 10 & -7.00 & 24.54 & -6.99 & 16.30 & 24.44 & Reject $\mathrm{H}_{0}$ \\
\hline Bangalore & 11 & -4.54 & 10.33 & -4.59 & 7.02 & 10.53 & Reject $\mathrm{H}_{0}$ \\
\hline Mumbai & 11 & -4.49 & 10.06 & -4.48 & 6.69 & 10.04 & Reject $\mathrm{H}_{0}$ \\
\hline Calcutta & 15 & -4.76 & 11.33 & -4.76 & 7.59 & 11.37 & Reject $\mathrm{H}_{0}$ \\
\hline Delhi & 16 & -4.47 & 10.02 & -4.46 & 6.65 & 9.96 & Reject $\mathrm{H}_{0}$ \\
\hline \multicolumn{8}{|c|}{ c) Second Difference Level } \\
\hline \multirow[b]{2}{*}{ Variable } & \multirow[b]{2}{*}{ Lags } & \multicolumn{2}{|c|}{ Constant, No Trend } & \multicolumn{2}{|c|}{ Constant, Trend } & \multicolumn{2}{|c|}{ Inference } \\
\hline & & $\mathbf{A}(\mathbf{1})=\mathbf{0}$ & $\begin{array}{c}\mathbf{A}(\mathbf{0})= \\
\mathbf{A}(\mathbf{1})=\mathbf{0}\end{array}$ & $\mathbf{A}(\mathbf{1})=\mathbf{0}$ & $\begin{array}{c}\mathbf{A}(0)= \\
\mathbf{A}(\mathbf{1})= \\
\mathbf{A}(2)=0\end{array}$ & $\begin{array}{c}\mathbf{A}(1)= \\
\mathbf{A}(2)=0\end{array}$ & \\
\hline $\begin{array}{l}\text { Critical value } \\
\text { (10 per cent) }\end{array}$ & & -2.57 & 3.78 & -3.13 & 4.03 & 5.34 & \\
\hline Hyderabad & 13 & -10.92 & 59.61 & -10.90 & 39.59 & 59.39 & Reject $\mathrm{H}_{0}$ \\
\hline Rajkot & 6 & -11.19 & 62.55 & -11.17 & 41.56 & 62.34 & Reject $\mathrm{H}_{0}$ \\
\hline Bangalore & 11 & -9.50 & 45.10 & -9.48 & 29.95 & 44.93 & Reject $\mathrm{H}_{0}$ \\
\hline Mumbai & 14 & -7.44 & 27.68 & -7.43 & 18.38 & 27.57 & Reject $\mathrm{H}_{0}$ \\
\hline Calcutta & 13 & -6.94 & 24.12 & -6.93 & 16.04 & 24.03 & Reject $\mathrm{H}_{0}$ \\
\hline Delhi & 5 & -10.93 & 59.76 & -10.92 & 39.73 & 59.60 & Reject $\mathrm{H}_{0}$ \\
\hline
\end{tabular}


Table 6: Unit Root Tests for Rapeseed and Mustard Oil Price Series in Selected Rapeseed and Mustard Oil Markets in India (1980-81 through 2003-04)

\begin{tabular}{|c|c|c|c|c|c|c|c|}
\hline \multicolumn{8}{|c|}{ a) Original Level } \\
\hline \multirow[b]{2}{*}{ Variable } & \multirow[b]{2}{*}{ Lags } & \multicolumn{2}{|c|}{ Constant, No Trend } & \multicolumn{3}{|c|}{ Constant, Trend } & \multirow[t]{2}{*}{ Inference } \\
\hline & & $\mathbf{A}(\mathbf{1})=0$ & $\begin{array}{c}\mathbf{A}(\mathbf{0})= \\
\mathbf{A}(\mathbf{1})=0\end{array}$ & $A(1)=0$ & $\begin{array}{c}\mathbf{A}(\mathbf{0})= \\
\mathbf{A}(\mathbf{1})= \\
\mathbf{A}(\mathbf{2})=\mathbf{0}\end{array}$ & $\begin{array}{c}\mathbf{A}(1)= \\
\mathbf{A}(2)=0\end{array}$ & \\
\hline \multirow{7}{*}{$\begin{array}{c}\text { Critical } \\
\text { value } \\
\text { (10 per cent) } \\
\text { Patna } \\
\text { Moga } \\
\text { Haryana } \\
\text { Kanpur } \\
\text { Calcutta } \\
\text { Delhi } \\
\end{array}$} & \multirow{7}{*}{$\begin{array}{c}4 \\
2 \\
15 \\
10 \\
10 \\
2\end{array}$} & \multirow{7}{*}{$\begin{array}{l}-2.57 \\
-0.81 \\
-2.23 \\
-1.40 \\
-0.95 \\
-0.72 \\
-1.21\end{array}$} & 3.78 & -3.13 & 4.03 & 5.34 & \multirow{7}{*}{$\begin{array}{l}\text { Accept } \mathrm{H}_{0} \\
\text { Accept } \mathrm{H}_{0} \\
\text { Accept } \mathrm{H}_{0} \\
\text { Accept } \mathrm{H}_{0} \\
\text { Accept } \mathrm{H}_{0} \\
\text { Accept } \mathrm{H}_{0}\end{array}$} \\
\hline & & & 1.13 & -3.52 & 4.84 & 6.43 & \\
\hline & & & 2.67 & -4.18 & 5.95 & 8.73 & \\
\hline & & & 1.39 & -2.26 & 2.06 & 2.67 & \\
\hline & & & 1.03 & -3.91 & 5.65 & 7.87 & \\
\hline & & & 0.90 & -3.84 & 5.61 & 7.73 & \\
\hline & & & 1.27 & -4.36 & 6.85 & 9.71 & \\
\hline \multicolumn{8}{|c|}{ b) First Difference Level } \\
\hline \multirow[t]{2}{*}{ Variable } & Lags & \multicolumn{2}{|c|}{ Constant, No Trend } & \multicolumn{3}{|c|}{ Constant, Trend } & Inference \\
\hline & & $A(1)=0$ & $\begin{array}{c}\mathbf{A}(\mathbf{0})= \\
\mathbf{A}(\mathbf{1})=\mathbf{0}\end{array}$ & $\mathbf{A}(1)=0$ & $\begin{array}{c}\mathbf{A}(0)= \\
\mathbf{A}(1)= \\
\mathbf{A}(2)=0\end{array}$ & $\begin{array}{c}\mathbf{A}(\mathbf{1})= \\
\mathbf{A}(2)=0\end{array}$ & \\
\hline $\begin{array}{c}\text { Critical } \\
\text { value } \\
\text { (10 per cent })\end{array}$ & & -2.57 & 3.78 & -3.13 & 4.03 & 5.34 & \\
\hline Patna & 9 & -5.57 & 15.50 & -5.62 & 10.55 & 15.82 & Reject $\mathrm{H}_{0}$ \\
\hline Moga & 10 & -5.74 & 16.46 & -5.73 & 10.93 & 16.40 & Reject $\mathrm{H}_{0}$ \\
\hline Haryana & 16 & -5.29 & 14.01 & -5.30 & 9.38 & 14.07 & Reject $\mathrm{H}_{0}$ \\
\hline Kanpur & 14 & -4.47 & 9.99 & -4.50 & 6.78 & 10.16 & Reject $\mathrm{H}_{0}$ \\
\hline Calcutta & 12 & -4.73 & 11.19 & -4.79 & 7.68 & 11.51 & Reject $\mathrm{H}_{0}$ \\
\hline Delhi & 10 & -5.67 & 16.09 & -5.73 & 10.99 & 16.47 & Reject $\mathrm{H}_{0}$ \\
\hline \multicolumn{8}{|c|}{ c) Second Difference Level } \\
\hline \multirow[b]{2}{*}{ Variable } & \multirow[b]{2}{*}{ Lags } & \multicolumn{2}{|c|}{ Constant, No Trend } & \multicolumn{2}{|c|}{ Constant, Trend } & \multicolumn{2}{|c|}{ Inference } \\
\hline & & $\mathbf{A}(\mathbf{1})=\mathbf{0}$ & $\begin{array}{c}\mathbf{A}(\mathbf{0})= \\
\mathbf{A}(\mathbf{1})=\mathbf{0}\end{array}$ & $\mathbf{A}(\mathbf{1})=\mathbf{0}$ & $\begin{array}{c}A(0)= \\
A(1)= \\
A(2)=0\end{array}$ & $\begin{array}{c}A(1)= \\
A(2)=0\end{array}$ & \\
\hline $\begin{array}{c}\text { Critical } \\
\text { value } \\
\text { (10 per cent })\end{array}$ & & -2.57 & 3.78 & -3.13 & 4.03 & 5.34 & \\
\hline Patna & 10 & -9.40 & 44.16 & -9.38 & 29.35 & 44.03 & Reject $\mathrm{H}_{0}$ \\
\hline Moga & 14 & -7.20 & 25.90 & -7.18 & 17.20 & 25.80 & Reject $\mathrm{H}_{0}$ \\
\hline Haryana & 13 & -7.31 & 26.75 & -7.30 & 17.76 & 26.64 & Reject $\mathrm{H}_{0}$ \\
\hline Kanpur & 10 & -9.08 & 41.26 & -9.07 & 27.40 & 41.11 & Reject $\mathrm{H}_{0}$ \\
\hline Calcutta & 12 & -8.21 & 33.69 & -8.20 & 22.39 & 33.58 & Reject $\mathrm{H}_{0}$ \\
\hline Delhi & 8 & -10.79 & 58.17 & -10.78 & 38.71 & 58.06 & Reject $\mathrm{H}_{0}$ \\
\hline
\end{tabular}

Table 7: Unit Root Tests for Castor Oil Price Series in Selected Castor Oil Markets in India (1980-81 through 2003-04)

\begin{tabular}{|c|c|c|c|c|c|c|c|}
\hline \multirow[b]{3}{*}{ Variable } & \multirow[b]{3}{*}{ Lags } & \multirow{2}{*}{\multicolumn{2}{|c|}{ Constant, No Trend }} & & & & \multirow{3}{*}{ Inference } \\
\hline & & & & \multicolumn{3}{|c|}{ Constant, Trend } & \\
\hline & & $\mathbf{A}(\mathbf{1})=\mathbf{0}$ & $\begin{array}{c}\mathbf{A}(\mathbf{0})= \\
\mathbf{A}(\mathbf{1})=\mathbf{0}\end{array}$ & $A(1)=0$ & $\begin{array}{c}\mathbf{A}(\mathbf{0})= \\
\mathbf{A}(\mathbf{1})= \\
\mathbf{A}(\mathbf{2})=\mathbf{0}\end{array}$ & $\begin{array}{c}\mathbf{A}(\mathbf{1})= \\
\mathbf{A}(2)=0\end{array}$ & \\
\hline $\begin{array}{l}\text { Critical value } \\
\text { (10 per cent) }\end{array}$ & & -2.57 & 3.78 & -3.13 & 4.03 & 5.34 & \\
\hline Hyderabad & 14 & -1.39 & -1.41 & -3.02 & 3.39 & 4.62 & Accept $\mathrm{H}_{0}$ \\
\hline Bangalore & 13 & -0.31 & 2.10 & -1.97 & 3.06 & 2.51 & Accept $\mathrm{H}_{0}$ \\
\hline
\end{tabular}




\begin{tabular}{|c|c|c|c|c|c|c|c|}
\hline $\begin{array}{l}\text { Mumbai } \\
\text { Chennai } \\
\text { Kanpur } \\
\text { Calcutta }\end{array}$ & $\begin{array}{c}13 \\
15 \\
15 \\
9 \\
\end{array}$ & $\begin{array}{l}-1.20 \\
-0.30 \\
-0.58 \\
-1.16 \\
\end{array}$ & $\begin{array}{l}1.78 \\
2.00 \\
1.52 \\
1.37 \\
\end{array}$ & $\begin{array}{l}-2.69 \\
-2.46 \\
-2.84 \\
-2.98 \\
\end{array}$ & $\begin{array}{c}3.20 \\
3.39 \\
3.63 \\
-3.46 \\
\end{array}$ & $\begin{array}{l}3.72 \\
3.09 \\
4.05 \\
4.47 \\
\end{array}$ & $\begin{array}{l}\text { Accept } \mathrm{H}_{0} \\
\text { Accept } \mathrm{H}_{0} \\
\text { Accept } \mathrm{H}_{0} \\
\text { Accept } \mathrm{H}_{0}\end{array}$ \\
\hline \multicolumn{8}{|c|}{ b) First Difference Level } \\
\hline \multirow[t]{2}{*}{ Variable } & Lags & \multicolumn{2}{|c|}{ Constant, No Trend } & \multicolumn{3}{|c|}{ Constant, Trend } & Inference \\
\hline & & $\mathbf{A}(\mathbf{1})=\mathbf{0}$ & $\begin{array}{c}\mathbf{A}(\mathbf{0})= \\
\mathbf{A}(\mathbf{1})=\mathbf{0}\end{array}$ & $\mathbf{A}(\mathbf{1})=\mathbf{0}$ & $\begin{array}{c}\mathbf{A}(0)= \\
\mathbf{A}(1)= \\
\mathbf{A}(2)=0\end{array}$ & $\begin{array}{c}\mathbf{A}(1)= \\
\mathbf{A}(2)=0\end{array}$ & \\
\hline $\begin{array}{l}\text { Critical value } \\
\text { (10 per cent) }\end{array}$ & & -2.57 & 3.78 & -3.13 & 4.03 & 5.34 & \\
\hline Hyderabad & 14 & -4.41 & 9.72 & -4.42 & 6.50 & 9.75 & Reject $\mathrm{H}_{0}$ \\
\hline Bangalore & 12 & -5.01 & 12.54 & -5.12 & 8.73 & 13.09 & Reject $\mathrm{H}_{0}$ \\
\hline Mumbai & 15 & -4.41 & 9.69 & -4.42 & 6.51 & 9.76 & Reject $\mathrm{H}_{0}$ \\
\hline Chennai & 16 & -4.47 & 10.00 & -4.48 & 6.68 & 10.02 & Reject $\mathrm{H}_{0}$ \\
\hline Kanpur & 16 & -3.78 & 7.14 & -3.77 & 4.74 & 7.12 & Reject $\mathrm{H}_{0}$ \\
\hline Calcutta & 14 & -4.29 & 9.21 & -4.28 & 6.12 & 9.18 & Reject $\mathrm{H}_{0}$ \\
\hline \multicolumn{8}{|c|}{ c) Second Difference Level } \\
\hline \multirow[b]{2}{*}{ Variable } & \multirow[b]{2}{*}{ Lags } & \multicolumn{2}{|c|}{ Constant, No Trend } & \multicolumn{2}{|c|}{ Constant, Trend } & \multicolumn{2}{|c|}{ Inference } \\
\hline & & $A(1)=0$ & $\begin{array}{c}\mathbf{A}(\mathbf{0})= \\
\mathbf{A}(\mathbf{1})=0\end{array}$ & $\mathbf{A}(\mathbf{1})=\mathbf{0}$ & $\begin{array}{c}\mathbf{A}(\mathbf{0})= \\
\mathbf{A}(\mathbf{1})= \\
\mathbf{A}(\mathbf{2})=\mathbf{0}\end{array}$ & $\begin{array}{c}\mathbf{A}(1)= \\
\mathbf{A}(2)=0\end{array}$ & \\
\hline $\begin{array}{l}\text { Critical value } \\
\text { (10 per cent) }\end{array}$ & & -2.57 & 3.78 & -3.13 & 4.03 & 5.34 & \\
\hline Hyderabad & 12 & -7.86 & 30.90 & -7.85 & 20.53 & 30.79 & Reject $\mathrm{H}_{0}$ \\
\hline Bangalore & 15 & -7.30 & 26.68 & -7.29 & 17.74 & 26.60 & Reject $\mathrm{H}_{0}$ \\
\hline Mumbai & 15 & -7.20 & 25.93 & -7.19 & 17.22 & 25.84 & Reject $\mathrm{H}_{0}$ \\
\hline Chennai & 13 & -7.42 & 27.52 & -7.41 & 18.28 & 27.42 & Reject $\mathrm{H}_{0}$ \\
\hline Kanpur & 16 & -6.75 & 22.78 & -6.74 & 15.13 & 22.70 & Reject $\mathrm{H}_{0}$ \\
\hline Calcutta & 14 & -6.28 & 19.74 & -6.27 & 13.11 & 19.67 & Reject $\mathrm{H}_{0}$ \\
\hline
\end{tabular}

Table 8: Unit Root Tests for Sesame Oil Price Series in Selected Sesame Oil Markets in India (1980-81 through 2003-04)

\begin{tabular}{|c|c|c|c|c|c|c|c|}
\hline a) Orig & al Leve & & & & & & \\
\hline \multirow[b]{2}{*}{ Variable } & \multirow[b]{2}{*}{ Lags } & \multicolumn{2}{|c|}{ Constant, No Trend } & \multicolumn{3}{|c|}{ Constant, Trend } & \multirow[t]{2}{*}{ Inference } \\
\hline & & $\mathbf{A}(\mathbf{1})=\mathbf{0}$ & $\begin{array}{c}\mathbf{A}(\mathbf{0})= \\
\mathbf{A}(\mathbf{1})=\mathbf{0}\end{array}$ & $\mathbf{A}(\mathbf{1})=\mathbf{0}$ & $\begin{array}{c}\mathbf{A}(\mathbf{0})= \\
\mathbf{A}(\mathbf{1})= \\
\mathbf{A}(\mathbf{2})=\mathbf{0}\end{array}$ & $\begin{array}{c}\mathbf{A}(\mathbf{1})= \\
\mathbf{A}(2)=0\end{array}$ & \\
\hline Critical value & & -2.57 & 3.78 & -3.13 & 4.03 & 5.34 & \\
\hline (10 per cent) & 16 & & & & & 1150 & 1 \\
\hline Hyderabad & 12 & -0.65 & 1.16 & -4.78 & 8.35 & 11.50 & \\
\hline Mumbai & 6 & -0.44 & 1.11 & -2.75 & 3.35 & 3.98 & Accept H0 \\
\hline Chennai & $\begin{array}{l}0 \\
0\end{array}$ & -0.87 & 1.73 & -2.86 & 4.15 & 4.44 & Accept H0 \\
\hline Varanasi & 0 & -1.74 & 1.75 & -2.72 & 2.64 & 3.71 & Accept H0 \\
\hline \multicolumn{8}{|c|}{ b) First Difference Level } \\
\hline \multirow[t]{2}{*}{ Variable } & Lags & \multicolumn{2}{|c|}{ Constant, No Trend } & \multicolumn{3}{|c|}{ Constant, Trend } & Inference \\
\hline & & $A(1)=0$ & $\begin{array}{c}\mathbf{A}(\mathbf{0})= \\
\mathbf{A}(\mathbf{1})=\mathbf{0}\end{array}$ & $A(1)=0$ & $\begin{array}{c}\mathbf{A}(\mathbf{0})= \\
\mathbf{A}(\mathbf{1})= \\
\mathbf{A}(\mathbf{2})=\mathbf{0}\end{array}$ & $\begin{array}{c}\mathbf{A}(\mathbf{1})= \\
\mathbf{A}(2)=0\end{array}$ & \\
\hline $\begin{array}{l}\text { Critical value } \\
\text { (10 per cent) }\end{array}$ & & -2.57 & 3.78 & -3.13 & 4.03 & 5.34 & \\
\hline Hyderabad & 12 & -4.03 & 8.12 & -4.03 & 5.43 & 8.14 & Reject $\mathrm{H}_{0}$ \\
\hline Mumbai & 12 & -4.09 & 8.37 & -4.13 & 5.68 & 8.52 & Reject $\mathrm{H}_{0}$ \\
\hline Chennai & 13 & -3.75 & 7.02 & -3.77 & 4.74 & 7.11 & Reject $\mathrm{H}_{0}$ \\
\hline Varanasi & 6 & -6.13 & 18.76 & -6.12 & 12.49 & 18.73 & Reject $\mathrm{H}_{0}$ \\
\hline
\end{tabular}




\begin{tabular}{|c|c|c|c|c|c|c|c|}
\hline \multirow[b]{3}{*}{ Variable } & & nce Lev & & & & & \\
\hline & \multirow[b]{2}{*}{ Lags } & \multicolumn{2}{|c|}{ Constant, No Trend } & \multicolumn{2}{|c|}{ Constant, Trend } & \multicolumn{2}{|c|}{ Inference } \\
\hline & & $\mathbf{A}(\mathbf{1})=\mathbf{0}$ & $\begin{array}{c}\mathbf{A}(\mathbf{0})= \\
\mathbf{A}(\mathbf{1})=0\end{array}$ & $\mathbf{A}(\mathbf{1})=\mathbf{0}$ & $\begin{array}{c}\mathbf{A}(\mathbf{0})= \\
\mathbf{A}(\mathbf{1})= \\
\mathbf{A}(\mathbf{2})=\mathbf{0}\end{array}$ & $\begin{array}{c}A(1)= \\
A(2)=0\end{array}$ & \\
\hline $\begin{array}{l}\text { Critical value } \\
\text { (10 per cent) }\end{array}$ & & -2.57 & 3.78 & -3.13 & 4.03 & 5.34 & \\
\hline Hyderabad & $\begin{array}{l}12 \\
12\end{array}$ & -8.88 & 39.45 & -8.86 & 26.21 & 39.30 & Reject $\mathrm{H}_{0}$ \\
\hline Mumbai & 12 & -8.11 & 32.87 & -8.09 & 21.84 & 32.75 & Reject $\mathrm{H}_{0}$ \\
\hline Chennai & $\begin{array}{l}15 \\
15\end{array}$ & -7.35 & 26.99 & -7.33 & 17.93 & 26.89 & Reject $\mathrm{H}_{0}$ \\
\hline Varanasi & & -6.67 & 22.25 & -6.66 & 14.78 & 22.16 & Reject $\mathrm{H}_{0}$ \\
\hline
\end{tabular}

The results showed that the oil markets in India were well integrated with a high degree of pricing efficiency. The values of correlation coefficients in most cases ranged between 0.8 and 0.9 and it was an indicator of high competition and thus high spatial pricing efficiency. The results are in conformity with the following studies such as Blyn (1973), Thakur (1973), Thakur (1974), Raju and Van Oppen (1982) and Acharya (1988).

Under Augmented Dicky Fuller (ADF) test, the commodities were selected which were similar under price series correlation. The results of this test showed that all oil markets in India were well integrated because the " $t$ " calculated values are greater than asymptotic critical values for all the price series are stationary and having the same order of integration denoted by 1 (1). The results are in conformity with the following studies conducted by Surajit Deb (2004), Pramod Kumar et al. (2003), Sunil (2003) and Thomas and Sundaresan (1996).

\section{CONCLUSIONS AND POLICY IMPLICATIONS}

All the selected oil markets were well integrated at the same order and there is existence of integration of prices between the selected oils markets in India. These results have important policy implications. In a situation when oil markets are spatially integrated the government may think of reducing or even withdrawing its efforts to influence the price in the market. The finding of the market integration appears to be quite significant for the success of price policy and market liberalization programs undertaken in India.

\section{REFERENCES}

1. Acharya S S 1988 Agricultural Production, marketing and price policy in India. Mittal Publications. pp:328.

2. Acharya, S S 2001 Domestic Agricultural Marketing Policies, Incentives and Integration in S. S. Acharya and D. P. Chaudhri (Eds.) (2001), Indian Agricultural Policy at the Crossroads, Rawat Publications, Jaipur.

3. Blyn G 1973 Price series correlation as a measure of market integration. Indian Journal of Agricultural Economics 28(2):5659

4. Chand, Ramesh 2007 Marketing and Trade Policies in a Globalizing World, 4th Parthasarthy Memorial Lecture delivered during the 21st Conference of Indian Society of Agricultural Marketing, published in Indian Journal of Agricultural Marketing, (Conference Special), 21(3).

5. Davidson, Russell and Mackinnon J G 1993 Estimation and inference in econometrics. Oxford University Press, New York.

6. Engle $R F$ and Granger CW J 1987 Co integration and error correction: Representation, estimation and testing Econometrical 55:251-276.

7. Fuller W A 1976 Introduction to stastical time series. Wiley, New York 
8. Granger C W J and New bold P 1977 forecasting economic time series. Academic Press, New York

9. Gujarati and Damoder N 1996 Basic Econometrics. Mc Graw Hill Incorporation, Newyork, and pp: 719.

10. Jha, Raghbendra, K. V. Bhanu Murthy and Anurag Sharma 2005 Market Integration in Wholesale Rice Markets in India ASARC Working Paper 03, Australian National University, Canberra, Australia.

11. Pramod Kumar, Sharma $R K$ and Kumar P 2003 Spatial price integration and pricing efficiency at the farm level: A study of paddy in Haryana. Indian Journal of Agricultural Economics 58(2):201-217.

12. Raju V T and Vonoppen M 1982 Marketing efficiency for selected crops in semi arid tropical India. Progress Report No.32, ICRISAT Economics Programme.

13. Sunil A 2003 The process of interactions between industry and agriculture in India: Evidence based on a multivariate co integration and error correction modeling approach. Indian Journal of Agricultural Economics 58(4):715-728.

14. Surjit Deb 2004 Terms of trade and investment behavior in Indian agriculture: A co integration analysis. Indian Journal of Agricultural Economics 59(2):209-229.

15. Thakur D S 1973 Pricing efficiency of the Indian apple market. Indian Journal of Agricultural Economics 28(1):105-114.

16. Thakur D S 1974 Food grain marketing efficiency: A case study of Gujarat. Indian Journal of Agricultural Economics 29(4):61-74.

17. Thomas $J$ K and Sundaresan R 1996 Export performance of cardamom in India. Bihar Journal of Agricultural Marketing $4(1): 29-34$. 